\title{
Upaya Meningkatkan Hasil Belajar Siswa Melalui Model Pembelajaran Problem Based Learning Pada Pembelajaran Produk Kreatif Dan Kewirausahaan Di SMK Negeri 1 Bulango Selatan
}

\author{
Sartin Halid \\ Guru SMKN1 Bulango Selatan \\ sartinhalid@gmail.com
}

Received: 13 August 2021; Revised: 02 October 2021; Accepted: 14 December 2021

DOI: http://dx.doi.org/10.37905/aksara.8.1.363-368.2022

\begin{abstract}
Abstrak
Penelitian ini bertujuan untuk meningkatkan Hasil Belajar Produk Kreatif dan Kewirausahaan siswa kelas XI SMK Negeri 1 Bulango Selatan dengan Model Pembelajaran Problem Based Learning. Tiap siklus terdiri dari tahap perencanaan, pelaksanaan, pengamatan, dan refleksi. Analisis data yang digunakan adalah analisis deskriptif kuantitatif dengan persentase perolehan skor hasil belajar dengan skor maksimal. Berdasarkan hasil penelitian disimpulkan bahwa (1) Model pembelajaran problem based learning sudah diterapkan dengan baik. (2) Respon siswa kelas XI terhadap Peningkatan Hasil Belajar Model Pembelajaran PBL menunjukkan respon positif dibuktikan dengan skor respon sebesar 81,02\%. (3) Peningkatan Aktivitas Hasil Belajar Pembelajaran PBL dapat meningkatkan Motivasi Belajar Produk kreatif dan kewirausahaan siswa kelas XI SMK Negeri 1 Bulango Selatan Tahun Ajaran 2019/2020, pada perhitungan hasil observasi terjadi peningkatan hasil belajar pada siklus I sebesar 73,55\% dan siklus II sebesar $85,12 \%$, peningkatan siklus I ke siklus II sebesar 11,57\%. Dengan cross check dilakukan melalui angket yang didistribusikan kepada siswa dapat disimpulkan pula bahwa terjadi peningkatan siklus I sebesar 74,04\% dan siklus II sebesar 82,72\%, peningkatan dari siklus 1 ke siklus II sebesar 8,68\%.
\end{abstract}

Kata kunci: model pembelajaran, problem based learning, hasil belajar

\section{PENDAHULUAN}

Sekolah Menengah Kejuruan merupakan salah satu sekolah menengah tingkat atas yang mengutamakan pembelajaran berupa $70 \%$ praktek dan $30 \%$ teori, dikarenakan lulusan SMK dituntut memiliki keahlian tertentu, dengan adanya pembelajaran yang lebih mengutamakan praktek tersebut nantinya siswa diharapkan memiliki keterampilan, kemampuan, dan keinginan untuk menjadi seorang wirausaha. Siswa SMK yang sedang menempuh pendidikan di sekolah di bentuk supaya nantinya setelah lulus dari sekolah para siswa tidak hanya berburu pekerjaan dan mengisi peluang kerja yang sudah ada di dunia kerja, tapi juga bisa menciptakan peluang usaha sendiri, namun pada kenyataannya lulusan Sekolah Menengah Kejuruan menyumbang angka pengangguran yang tidak bisa dikatakan sedikit dari pada lulusan jenjang pendidikan yang lain, mereka mengalami kebimbangan memutuskan langkah apa yang selanjutnya akan ditempuh setelah lulus dikarenakan pada dasarnya siswa dilatih untuk menjadi lulusan yang siap bekerja namun tuntutan dilapangan saat ini lebih diutamakan lulusan dari perguruan tinggi.

Mata pelajaran Produk Kreatif dan Kewirausahaan diajarkan untuk memberikan pengetahuan dan keterampilan lebih kepada siswa mengenai kewirausahaan, serta diharapkan dapat menumbuhkan minat siswa untuk berwirausaha. Siswa yang nantinya 
tidak melanjutkan keperguruan tinggi diharapkan memiliki minat yang lebih untuk berwirausaha, tidak hanya berburu pekerjaan atau bahkan menambah angka pengangguran. Mata pelajaran Produk kreatif dan Kewirausahaan memiliki peran dan kontribusi untuk menumbuhkan minat berwirauaha siswa, karena Mata pelajaran PKK di SMK Negeri 1 Bulango Selatan tidak hanya tentang menerapkan teori dan materimateri saja, namun pada proses pembelajarannya guru juga mengajarkan bagaimana siswa memperaktekkan secara langsung, belajar berwirausaha dari hal-hal kecil untuk melatih keberanian siswa dan memupuk mental dan minat berwirausaha mereka, dan mengarahkan minat berwirausaha mereka berdasarkan jurusan yang mereka tempuh disekolah, sehingga hasil belajar yang mereka peroleh bukan hanya sekedar teori, tapi juga pengalaman yang nantinya dapat membangun minat berwirausaha mereka setelah lulus dari bangku sekolah.

Guru memberi tugas praktek membuat produk dengan ide yang baru yang memiliki nilai jual dan kegiatan lain yang dapat menunjang hasil belajar pada mata pelajaran Produk Kreatif dan Kewirausahaan, berkaitan dengan hal tersebut, siswa diharapkan bisa lebih aktif untuk mempelajari peristiwa-peristiwa produk kreatif dan kewirausahaan yang terjadi di lingkungannya dan lebih terbuka terhadap peluangpeluang usaha yang ada. Proses pembelajaran tersebut diharapkan dapat mengembangkan segala potensi yang dimiliki oleh siswa dengan mengarahkan mereka untuk menjadi orang yang lebih produktif serta memiliki pengetahuan yang lebih luas. Keberhasilan pembelajaan dapat dilihat dari hasil belajar peserta didik, jika peserta didik mampu manguasai apa yang mereka pelajari sesuai dengan tujuan pembelajaran yang diharapkan maka dapat di katakan proses pembelajaran tersebut telah berhasil. Mata pelajaran produk kreatif dan kewirausahaan bertujuan agar peserta didik dapat mengaktualisasikan diri dalam perilaku berwirausaha, terlebih lagi bagi siswa SMK yang diharapkan memliki bekal keterampilan lebih nyata. Berdasarkan latar belakang tersebut, masalah yang ada dalam penelitian ini yaitu apakah ada pengaruh hasil belajar mata pelajaran produk kreatif dan kewirausahaan terhadap minat berwirausaha siswa di SMK Negeri 1 Bulango Selatan.

Salah satu permasalahan yang dihadapi pada proses kegiatan pembelajaran sekarang ini adalah rendahnya minat siswa untuk belajar dan dalam mengikuti aktivitas pembelajaran. Permasalahan pada pembelajaran Produk Kreatif dan Kewirausahaan (PKK) antara lain sering ditemukan guru yang kurang mampu menghubungkan relevansi pelajaran dengan kenyataan praktis dan keterkaitannya dengan ilmu-ilmu lain, situasi dan kondisi belajar yang tidak nyaman dan kurang variatif, minimnya penggunaan media, guru cenderung menggunakan model pembelajaran konvensional. Hasil studi pendahuluan pada proses pembelajaran pada kelas XI semester ganjil di SMK Negeri 1 Bulango Selatan tahun pelajaran 2019/2020 adalah sebagai berikut:

1. Rendahnya hasil belajar siswa pada mata pelajaran PKK.

2. Metode belajar problem solving belum pernah diterapkan pada kompetensi menghitung biaya produksi prototype produk barang/jasa di SMK Negeri 1 Bulango Selatan pada mata pelajaran PKK.

Pada semester ganjil tahun pelajaran 2019/2020 nilai rata-rata diperoleh siswa 65,45 dan rata-rata nilai kelas untuk UTS adalah 66,50, dan rata-rata ulangan semester 65,30 . Dari hasil resume dan hasil analisis soal ternyata dari jumlah siswa 22 orang pada kelas XI yang menjadi subyek penelitian ini yang masih menjawab salah pada materi 
hitungan fungsi konsumsi, tabungan dan investasi sebanyak 45,45\% atau sebanyak 10 orang.

Kemudian yang mencapai nilai KKM hanya 54,54\% atau hanya sekitar 12 orang saja. Kondisi tersebut menunutut guru untuk melakukan remedial karena masih banyaknya siswa yang masih berada dibawah kriteria ketuntasan minimal (KKM) yang ditentukan untuk mata pelajaran produk kreatif dan kewirausahaan kelas XI adalah 75. Dari hasil belajar di atas dapat disimpulkan bahwa hasil belajar siswa untuk ulangan harian, ulangan tengah semester serta ulangan semester genap masuk dalam kategori sedang. Setelah ditelusuri dari resume pembelajaran yang dibuat oleh guru pada setiap pertemuan, penyebab munculnya permasalahan di atas disebabkan oleh beberapa hal, yaitu; 1) materi hitungan pada mata pelajaran produk kreatif dan kewirausahaan sulit dipahami sehingga siswa terlihat dari hasil penilaian diri siswa. 2) guru sudah menerapkan model-model pembelajaran, namun sebagian siswa masih hanya sebatas pada menghafalkan materi yang ada dalam buku cetak, belum mampu memberikan contoh atau menjelaskan konsep berdasarkan pemahaman sendiri, hal ini terlihat dari jawaban dari siswa jika diberikan soal yang agak berbeda dengan buku meskipun masih dalam konteks yang sama siswa tidak dapat menjawabnya dengan benar; 3) siswa jarang mengajukan pertanyaan, walaupun guru sering meminta agar siswa bertanya jika ada hal-hal yang belum jelas, atau kurang paham; 4) keaktifan dalam mengerjakan soal-soal latihan pada proses pembelajaran juga masih kurang; 5) kurangnya keberanian siswa untuk mengemukakan gagasan/pendapat dalam pembelajaran; dan 6) kurangnya keberanian siswa dalam mengerjakan soal di depan kelas, hal ini menggambarkan efektifitas belajar mengajar dalam kelas masih rendah. Akitivitas siswa yang rendah tersebut dapat berdampak pada rendahnya pemahaman siswa terhadap materi pembelajaran yang diberikan guru, sehingga siswa menjadi rentan tidak lulus mata pelajaran produk kreatif dan kewirausahaan.

Untuk mengatasi kesulitan pemahaman tersebut, maka perlu dilakukan upaya untuk meningkatkan hasil belajar siswa pada mata pelajaran produk kreatif dan kewirausahaan. Salah satu diantaranya adalah melalui penerapan pendekatan, metode serta model pembelajaran yang sesuai, yang dapat merangsang munculnya gagasan baru bukan hanya sekedar menghaflkan materi yang sudah ada dalam buku cetak mereka. Oleh sebab itu diperlukan metode belajar yang mampu meningkatkan minat serta hasil belajar siswa.

\section{KAJIAN TEORITIS}

Belajar merupakan keharusan yang dilakukan oleh setiap orang yang berpengaruh terhadap tingkah laku, cara berpikir dan pandangan seseorang dalam menyelesaikan suatu masalah. Dengan belajar diharapkan pengetahuan seseorang akan bertambah sehingga mampu menghadapi segala macam tantangan kehidupan. Menurut Slameto (2010: 2), "belajar ialah suatu proses usaha yang dilakukan oleh seseorang untuk memperoleh suatu perubahan tingkah laku yang baru secara keseluruhan, sebagai hasil pengalamannya sendiri dalam interaksi dengan lingkungannya", Menurut Hamdani (2010: 71), "belajar adalah seperangkat proses kognitif yang mengubah sifat stimulasi lingkungan, melalui pengolahan informasi, menjadi kapabilitas baru", sedangkan menurut Syaiful Bahri Djamarah dan Aswan Zain (2006: 10), "belajar adalah proses perubahan perilaku berkat pengalaman dan latihan". 
Hasil belajar siswa pada hakikatnya adalah pola-pola perbuatan, nilai-nilai, pengertian-pengertian, sikap-sikap, apresiasi dan keterampilan (Agus Suprijono, 2011: 5). Menurut Bloom hasil belajar meliputi kemampuan kognitif, afektif, dan psikomotorik Menurut Agus Suprijono, (2011: 6),"hasil belajar adalah perubahan perilaku secara keseluruhan bukan hanya salah satu aspek potensi kemanusiaan saja". Menurut Dimyati dan Mudjiono (2009: 3), "Berpendapat bahwa hasil belajar merupakan hasil dari suatu interaksi tindak belajar dan tindak mengajar"

Model pembelajaran problem solving adalah model pembelajaran yang menyajikan materi dengan menghadapkan siswa kepada persoalan yang harus dipecahkan. Problem solving adalah suatu proses mental dan intelektual dalam menemukan suatu masalah dan memecahkannya berdasarkan data dan informasi yang akurat, sehingga dapat diambil kesimpulan yang tepat dan cermat. Proses problem solving memberi kesempatan kepada siswa untuk berperan aktif dalam mempelajari, mencari, dan menemukan sendiri informasi dan diolah menjadi konsep, prinsip, teori, atau kesimpulan. Metode problem solving menuntut kemampuan memroses informasi untuk membuat keputusan tertentu (Hidayati, 2006).

Metode problem solving sebagai strategi pembelajaran erat kaitannya dengan inkuiri dan penemuan. Pada inkuiri, yang dipentingkan ialah mencari jawaban sampai pada tingkat yakin dengan menggunakan dukungan fakta, analisa, interprestasi serta pembuktiannya. Pada problem solving titik berat diletakkan pada pemecahan masalah secara rasional, logis, benar dan epat, tekanan pada proses pemecahan masalah dengan penentuan alternatif yang berguna saja. Artinya, tidak sampai mengejar hakikat, lebih ditekankan pada kegunaannya, untuk memecahkan masalah. Landasan pemecahan masalah ialah berfikir kritis atau refleksi. Proses dalam cara berfikir adalah menyadari adanya masalah, mencari petunjuk pemecahannya serta menggunakan pemecahan yang cocok.

\section{METODE PENELITIAN}

Penelitian dilaksanakan dengan menggunakan metode penelitian tindakan kelas (PTK) model Kemmis dan Mc Taggart Instrumen yang digunakan untuk mengukur hasil belajar disusun dalam bentuk tes obyektif dan tes essay. Data lain yang perlu dikumpulkan untuk menunjang penelitian ini adalah deskripsi proses tindakan yang diperoleh melalui pengamatan selama kegiatan pembelajaran berlangsung. Kegiatan observasi dilakukan dengan bantuan rekan sejawat, yaitu guru mata pelajaran produk kreatif dan kewirausahaan di SMK Negeri 1 Bulango Selatan sebagai observer. Data tes hasil belajar akan dianalisis dengan statistik deskriptif seperti rata-rata dan presentase sedangkan data-data observasi dan wawancara akan dianalisis secara kuantitatif.

\section{HASIL PENELITIAN DAN PEMBAHASAN}

Peningkatan persentase skor Hasil Belajar Produk kreatif dan kewirausahaan yang diambil melalui observasi dengan lembar observasi diperoleh skor sebesar 41,87\% sebelum Implementasi Model Pembelajaran Problem Based Learning kemudian meningkat menjadi $73,55 \%$ pada Siklus I. Pada Siklus II terjadi peningkatan sebesar $11,57 \%$ atau diperoleh skor sebesar $85,12 \%$. Selain itu berdasarkan angket yang didistribusikan kepada siswa dapat disimpulkan bahwa terjadi peningkatan skor Hasil Belajar Produk Kreatif dan Kewirausahaan sebesar 8,68\% dimana skor pada Siklus I 
sebesar $74,04 \%$ meningkat menjadi $82,72 \%$ pada Siklus II. Selain itu respon siswa Kelas XI Semester Ganjil SMK Negeri 1 Bulango Selatan terhadap Implementasi Model Pembelajaran Problem Based Learning menunjukkan respon positif.

Dari data observasi dan angket yang diperoleh dapat disimpulkan bahwa dengan dilakukannya Implementasi Model Pembelajaran Problem Based Learning dapat meningkatkan Hasil Belajar Produk Kreatif dan Kewirausahaan Siswa Kelas XI Semester Ganjil SMK Negeri 1 Bulango Selatan tahun ajaran 2019/2020.

\section{KESIMPULAN}

Berdasarkan hasil penelitian disimpulkan bahwa Peningkatan Aktivitas Dan Hasil Belajar Produk Kreatif dan Kewirausahaan Melalui Model Pembelajaran Problem Based Learning Pada Siswa Kelas XI SMK Negeri 1 Bulango Selatan Kabupaten Bone Bolango Provinsi Gorontalo Tahun Pelajaran 2019/2020 mengalami perubahan kearah yang lebih baik, serta dengan dilakukannya Implementasi Model Pembelajaran Problem Based Learning dapat meningkatkan Hasil Belajar Produk Kreatif dan Kewirausahaan Siswa Kelas XI Semester Ganjil SMK Negeri 1 Bulango Selatan tahun ajaran 2019/2020.

Berdasarkan hasil dan kesimpulan penelitian ini, penulis memberikan saran: a). Guru sebaiknya mampu menerapkan berbagai macam variasi model pembelajaran untuk menciptakan proses pembelajaran yang menyenangkan sehingga mampu mendorong siswa untuk belajar secara maksimal. b). Guru dapat mencoba untuk melakukan Implementasi Model Pembelajaran Problem Based Learning pada kompetensi dasar yang lain, yang diharapkan dapat memicu Hasil

Belajar Produk Kreatif dan Kewirausahaan lebih tinggi lagi.

\section{DAFTAR PUSTAKA}

Daryanto (2010). Belajar dan Mengajar. Bandung: Yrama Widya.

Hidayati, M., 2006, Model Problem Solving untuk Meningkatkan Hasil Belajar Kalor dan Perpindahannya pada Siswa MTsN 1 Tanjung Karang, Sskripsi, FKIP Unila, Bandar Lampung.

Sanjaya, Wina. (2006). Strategi Pembelajaran, Berorientasi Standar Proses Pendidikan. Jakarta: Prenada Media Group.

Slameto. (2003). Belajar dan Faktor-faktor yang Mempengaruhinya. Jakarta: Rineka Cipta.

Sudjana, Djudju. (2000) Strategi Pembelajaran. Bandung: Falah, 2000 
AKSARA: Jurnal Ilmu Pendidikan Nonformal

P-ISSN 2407-8018 E-ISSN 2721-7310 DOI prefix 10.37905

Volume 08, (1), January 2022

http://ejurnal.pps.ung.ac.id/index.php/Aksara 